\title{
Age-dependent differences in iris colouration of passerines during autumn migration in Central Europe
}

\author{
Michał Polakowski ${ }^{\text {Corresp., } 1}$, Krzysztof Stępniewski ${ }^{2}$, Joanna Sliwa-Dominiak ${ }^{1}$, Magdalena Remisiewicz ${ }^{2}$ \\ 1 Institute of Biology, University of Szczecin, Szczecin, Poland \\ 2 Bird Migration Research Station, Faculty of Biology, University of Gdańsk, Gdańsk, Poland \\ Corresponding Author: Michał Polakowski \\ Email address: michal.polakowski@usz.edu.pl
}

Avian eye colour is a subject of various research, but many aspects are still insufficiently understood. Here we studied whether sex, age, species and body condition are related to the iris colour in common migratory passerines during their autumn passage through Central Europe. Total of 1221 individuals from nine numerous species were ringed and examined in late autumn in the northern Poland. Each individual was assigned to one of three classes of the iris colour - typical for immatures, typical for adults and intermediate. We found that the iris was typical in $97.80 \%$ cases of immatures and in $70.28 \%$ cases of adults and those differences were significant. Species, sex and body mass index (BMI) had no significant influence on the iris colour. We show that iris colour in passerines in the late autumn is strongly age-dependent and thus may serve as a reliable feature for age determination in field studies. 


\section{Age-dependent differences in iris colouration of} 3 passerines during autumn migration in Central

4 Europe

5

6 Michał Polakowski ${ }^{1}$, Krzysztof Stępniewski ${ }^{2}$, Joanna Śliwa-Dominiak ${ }^{1}$, Magdalena

$7 \quad$ Remisiewicz ${ }^{2}$

8

9 Institute of Biology, University of Szczecin, Szczecin, Poland

10 2Bird Migration Research Station, Faculty of Biology, University of Gdańsk, Gdańsk, Poland

12 Michał Polakowski

13 Institute of Biology, University of Szczecin, Wąska 13, 71-412, Szczecin, Poland

14 E-mail address: michal.polakowski@usz.edu.pl

15

16 


\section{Abstract}

In many bird species eye colour changes with age, but aspects of this transition are still

insufficiently understood. We examined if an individual's iris colour was related to species, sex, age and body condition in common migratory passerines during their autumn passage through Central Europe. We examined 1221 individuals of nine species when ringing birds in northern

23

\section{Introduction}

The colour of bird's eyes is an important, sometimes even striking or diagnostic, part of overall

34 colouration. The source of the colour is pigments located in the iris, including melanines, carotenoids, pteridines and purines (Bond, 1919; Oliphant, 1987; Hudon \& Muir, 1996; Prum, 1999). Contrary to humans, the sclera of a bird's eye is not visible, hence the eye colour is the

37 colour of the iris (Davidson, Thornton \& Clayton, 2017). Although most birds have dark eyes, 
39 related to size (Worthy, 1978), feeding strategy (Craig \& Hulley, 2004), communication between

40 individuals (Davidson, Clayton \& Thornton, 2014) or breeding behaviour (Davidson, Thornton

41 \& Clayton, 2017). A large inter- and intraspecific variety of eye colours exist in birds, sometimes

42 connected with sex but mostly with the age of an individual (Newton \& Marquiss, 1982; Sweijd

43 \& Craig, 1991; Bortolotti, Smits \& Bird, 2003; Wilson \& Hartley, 2007; Nogueira \& Alves,

44 2008; Mérő \& Žuljević, 2015). Immature birds usually have dark irises, which turn paler or

45 brighter as they mature. This phenomenon has been described and used for age determination in

46 several families, including penguins, waterfowl, raptors, gulls and some passerines (Trauger,

47 1974; Snyder \& Snyder, 1974; Newton \& Marquiss, 1982; Rosenfield \& Bielefeldt, 1997;

48 Scholten, 1999; Bortolotti, Smits \& Bird, 2003). However, the source of this variety and its

49 potential use for ageing more extensively, as well as the general role of avian eye colour, remain

50 poorly understood (Sweijd \& Craig, 1991; Bortolotti, Smits \& Bird, 2003; Craig \& Hulley, 2004;

51 Negro, Blázquez \& Galván, 2017).

52 Most Palaearctic passerines have dark eyes (Craig \& Hulley, 2004), the few exceptions

53 include the Jackdaw Crovus monedula, Jay Garrulus glandarius and Bearded Reedling Panurus

54 biarmicus. Changes of eye colour with age have been studied in detail in a few species of

55 passerines, especially at Falsterbo Bird Observatory in Sweden (e.g. Karlsson, Persson \&

56 Walinder, 1986; Brensing, 1985; Karlsson, Persson \& Walinder, 1988; Gargallo, 1992; Karlsson,

57 Persson \& Walinder, 1993; King \& Muddeman, 1995; Wilson \& Hartley, 2007; Mérő \&

58 Žuljević, 2015). Handbooks of bird identification in hand describe iris colour as a generally

59 reliable supporting feature for ageing passerines, along with plumage characters and skull

60 ossification (Svensson, 1992; Demongin, 2016), but details are given mostly for species with

61 reddish eyes, such as Dunnock Prunella modularis and Crested Tit Lophophanes cristatus 
62 (Svensson, 1992), for those whose adults have clearly pale irises, such as some Sylvia and

63 Acrocephalus species (e.g. Common Whitethroat S. communis and Eurasian Reed Warbler A.

64 scirpaceus; Karlsson, Persson \& Walinder, 1985; 1988), but for only a few dark-eyed species,

65 such as Reed Bunting Emberiza schoeniclus or Tree Pipit Anthus trivialis, Karlsson, Persson \&

66 Walinder, 1985; 1993). We are unaware of any study testing the reliability of this feature as an

67 additional means of ageing on a larger sample of dark-eyed passerines.

68 We aimed to determine the age-dependent iris colour of several dark-eyed passerines that

69 migrate in large numbers through Central Europe in late autumn. We also checked the potential

70 influence of sex and body condition on this trait, expecting the relationship to be universal and

71 unaffected by sex or body condition, making iris colour a reliable supporting feature in the

72 ageing of these passerines.

\section{Materials \& Methods}

75

76

77

Data were collected at the Bukowo-Kopan bird ringing station on the southern Baltic coast of northern Poland (5420'15' 'N, 16 $14^{\prime} 40^{\prime}$ 'E). The station operates within the Operation Baltic Research and Monitoring Programme, conducted by the Bird Migration Research Station, Faculty of Biology, University of Gdańsk. Migrating passerines were captured in 60 mist nets, located mainly in broad-leaved shrubs on the edge of marshy forest and sand dunes. Nets were checked every hour from dawn till dusk. All the captured birds were ringed, sexed and aged as first calendar-year birds (hereafter immatures) or older (adults). From each bird a set of biometric measurements was collected, including fat score, wing length (maximum chord) and mass to an accuracy of $0.1 \mathrm{~g}$; for more details see Busse \& Meissner, 2015. 
86 6th November 2019, which provided a sufficiently large sample for analysis (Table 1). Birds

87 were assigned to one of three classes of iris colour (Fig. 1, 2):

88 a) class 1: iris typical for immatures - dark grey, without any brown, contrasting only slightly 89 with the pupil,

90 b) class 2: iris typical for adults - paler and contrasting with the pupil, always with a visibly 91 warm brownish colour,

92 c) class 3: intermediate iris colour, pale and contrasting with the pupil (as in class 2), but greyish 93 without an obvious brownish colour.

94 The apparent colour of the iris to an observer could partially result from ambient light, so colour 95 was always determined in daylight with good visibility. To avoid observer bias, the iris colour 96 was determined and all the ringing data were collected by one of the authors (MP), who has 97 ringed about 100000 birds during over 20 years in Poland and Sweden. The birds were aged 98 based on plumage features and skull ossification, and sexed according to plumage whenever 99 possible (Svensson, 1992, Demongin, 2016). Robins Erithacus rubecula, which lack sexually 100 dimorphic plumage, were sexed on the basis of wing length, according to Polakowski \& 101 Jankowiak, 2012. Using the wing length criteria of adult male $>75 \mathrm{~mm}$ and adult female $<72$ $102 \mathrm{~mm}$, with immature male $>74 \mathrm{~mm}$ and immature female $<71 \mathrm{~mm}$, we successfully sexed $29.6 \%$ 103 of the Robins we caught. To avoid the bias of self-suggestion by unconsciously assigning the iris 104 colour to the class compliant with the age identified by plumage, we adopted two ways of 105 identification: in $63 \%$ of individuals their age was first identified by iris colour and then checked 106 by plumage, and in $37 \%$ the other way around. The overall numbers of birds we examined and

107 their eye colour classes are given in Table 1. All the bird ringing was conducted with the 
108 approval of the General Directorate for Environmental Protection in Poland (DZP-

109 WG.6401.03.2.2018.jro). Field research at Bukowo was approved by the Marine Office in

110 Słupsk (OW-A-510/100/19jt).

111 We tested the relation between age and iris colour using the Chi-square $\left(\chi^{2}\right)$ test of

112 independence. Then we checked if age or species increased the odds of an iris colour non-

113 compliant with age class using a generalised linear model (GLM) with binomial error

114 distribution. The dependent variable was compliance $(1=$ compliant, $0=$ non-compliant $)$; the

115 classes of iris colour were coded as: class 1 (grey) iris of immatures $=1$, class 2 (brown) iris of

116 adults $=1$, class 3 (intermediate) iris of immatures $=0$, class 3 (intermediate) iris of adults $=0$.

117 Adults with the immature type of iris (class 1 ) were considered in the model as 0 (non-

118 compliant). We used age, species and body mass index (BMI), calculated as body mass divided

119 by wing length, as explanatory variables. Not all individuals could be sexed, so we used a

120 smaller data set to analyse the effect of sex, which we added to the variables in the previous

121 model. We also added the age identification sequence (first iris then the other traits, or the other

122 way around) as an explanatory variable to check if it had affected the results. Statistical analyses

123 were performed using R software 3.6.1 (R Development Core Team, 2014), with a significance

124 level of $\mathrm{p}<0.05$.

125

126 Results

127

128 The iris colour was typical in $97.80 \%$ of our sample (1201 compliant - class 1, vs 27

129 intermediate - class 3 ) of immatures and in 70.28\% (175 compliant - class 2, vs 52 intermediate 
130 - class 3) of adults, when all species were combined. This difference was statistically significant

$131\left(\chi^{2}=160.1, p<0.001\right)$. In adults the iris colour was 13.1 times more likely to be intermediate

132 than in immatures $\left(\beta_{\text {Intercept }}=-4.013 \pm 0.230 \mathrm{SE} ; \beta_{\text {Age[adults] }}=2.569 \pm 0.253 \mathrm{SE}, \chi^{2}=107.163, \mathrm{p}<\right.$

1330.001 ). Thus, $93.1 \%-100 \%$ of immatures, depending on the species, were aged correctly by iris

134 colour, but in adults the accuracy of ageing by this trait was $62.5 \%-100 \%$ in different species

135 (Table 1). If a bird was aged first according to other traits, the chance was 1.84 times greater that

136 the iris would be judged to be intermediate than if it was aged by the iris colour first ( $\beta_{\text {Identification }}$

137 method [other traits] $\left.=0.610 \pm 0.248 \mathrm{SE}, \chi^{2}=6.043, \mathrm{p}=0.014\right)$. The effect of species on the probability

138 of the iris colour meeting expectations was not significant $\left(\chi^{2}=8.956, p=0.346\right)$, neither were

139 the effects of the body mass index (BMI, $\left.\chi^{2}=2.157, p=0.142\right)$ or $\operatorname{sex}\left(\chi^{2}=0.133, p=0.715\right)$.

\section{Discussion}

142

143 Our results show that iris colour is a reliable character for determining age in a large set of

144 passerine species on autumn migration, particularly for immatures (almost $98 \%$ consistency). We

145 suggest the use of the iris colour particularly in species in which ageing by other criteria is not

146 straightforward, as the Long-tailed Tit Aegithalos caudatus and Eurasian Treecreper Certhia

147 familiaris (Table 1). In other species it can be used as an additional supporting ageing criterion,

148 in concordance with suggestion from the studies from Falsterbo Bird Observatory, on a different

149 set of species than we examined (e.g. Karlsson, Persson \& Walinder, 1988; Karlsson, 2016). As

150 the consistency between this trait and the age of an individual was greater when age was

151 determined first by iris colour and then by plumage (and not the other way around), ageing by

152 the iris colour seem to be a good criterion when applied first and intuitively, but can undergo an 
153 unconscious bias when used after other criteria. Thus, we suggest that the ringers using the iris

154 colour, identify it first, before examination of plumage.

155 Most adults were aged correctly by iris colour, but the proportion of adults that did not 156 match the typical colour and had the intermediate or even immature (3 individuals) type of iris

157 was larger than among immatures in all species (Table 1). Perhaps the progression towards the

158 brownish hue typical for adults is subject to individual variation; for some non-passerines this

159 process takes longer than a year (Newton \& Marquiss, 1982; Karlsson, Persson \& Walinder,

160 1988; Bortolotti, Smits \& Bird, 2003). This could be supported by the cases of two adult birds in

161 our study showing an intermediate iris colour, one Robin and one Chaffinch Fringilla coelebs.

162 Both had been ringed locally in spring 2019 as second calendar year birds. During our study in

163 autumn 2019 they would have been $c a .1 .5$ years old (Nowakowski et al., 2012). Though these

164 individuals had already attained their adult plumage after a complete summer moult and did not

165 differ from older individuals by plumage, their iris colour had still not attained its proper adult

166 tinge. This suggests that iris colour might be used to distinguish individuals in the second

167 calendar year of life among birds in adult plumage, which has been shown in some species (e.g.

168 Eurasian Reed Warbler or Willow Warbler Phylloscopus trochilus; Karlsson, Persson \&

169 Walinder, 1988; Karlsson, 2016). This characteristic should be confirmed for each species during

170 moult, when it is still possible to identify these individuals by plumage. However, in the Great

171 Reed Warbler Acrocephalus arundinaceus adult birds of known age changed their eye colour

172 between recaptures both ways, from immature to adult type and vice versa, with similar

173 frequency (Mérő \& Žuljević, 2015). This phenomenon awaits further study, possibly with a set

174 of recaptured adult birds whose precise age is known. 

sexual dimorphism in this trait has been described for only a few species, such as the European

177 Starling Sturnus vulgaris (Smith et al., 2005). Sexual hormones might influence iris colour in 178 some species of birds (Trauger, 1974; Feare et al., 2015), as well as the timing when the adult 179 type of iris is attained in males and females (Newton \& Marquiss, 1982; Rosenfield \& Bielefeldt, 180 1997). Our results suggest that iris colour is not related to sex in the species we studied and that could be sexed by plumage. This timing should be tested by further research in the breeding season, when sexual hormone activity is more pronounced. Similarly, we did not find any relation between the colour of irises and the physiological condition of birds. Thus it seems that this trait is not influenced by metabolic pathways during migration and therefore it can be used as a reliable age criterion, unaffected by the bird's physical state, which changes rapidly during migration.

\section{Conclusions}

Our study demonstrates that the variation of iris colour in passerines in late autumn is strongly age-related and unaffected by sex or the condition of an individual. Iris colour can therefore be recommended as an additional ageing criterion for a larger set of species than previously differences between juveniles and adults, as well as for species that undergo a complete postjuvenile moult and do not display differences between age classes. The Long-tailed Tit is a good example of this category; but the technique would require further testing on a sample of adults during moult. This method has proven more reliable for immatures than adults. Birds with an 
198 intermediate iris colour should not be aged upon this character alone. This method does require 199 experience in recognizing the categories of iris colour and we recommend testing the method by 200 comparison with other traits and with the help of an experienced ringer. Potential variations of 201 iris colour in other stages of a bird's life cycle, as well as any influence of other factors, await 202 further studies.

203

\section{Acknowledgements}

205

206 Monika Broniszewska, Joanna Rogozińska, Jacek Rogoziński and other volunteers at the 207 Bukowo ringing station made a considerable contribution to this study. Monika Broniszewska 208 and Anna Woźnicka helped to create the database for this study. Tomasz Cofta, Artur Goławski,

209 Łukasz Jankowiak, Jarosław K. Nowakowski, Adrian Surmacki and Liliana Sadzik helped to 210 improve this manuscript. Michael Wink, Jonas Waldenström and Jochen Dierschke provided 211 useful comments on the earlier version of the paper. Joel Avni commented on and edited earlier 212 drafts. 


\section{References}

214

215 Bond CJ. 1919. On certain factors concerned in the production of eye colour in birds. Journal of

216 Genetics 9: 69-81.

217

218 Bortolotti GR, Smits JE, Bird D.M. 2003. Iris colour of American kestrels varies with age, sex, 219 and exposure to PCBs. Physiological and Biochemical Zoology 76 (1): 99-104.

220

221

Brensing D. 1985. Alterskennzichen bei Sumpf- und Teichrohrsänger (Acrocephalus palustris, 222 A. scirpaceus): Quantitative Untersuchung. Journal of Ornithology 126: 125-153.

223

224

Busse P, Meissner W. 2015. Bird ringing station manual. Warsaw: De Gruyter Open Ltd.

225

226

Craig AJFK \& Hulley PE. 2004. Iris colour in passerine birds: why be bright-eyed? South

227 African Journal of Science 100 (11-12): 584-588.

228

229

Davidson GL, Clayton NS, Thornton A. 2014. Salient eyes deter conspecific nest intruders in 230 wild jackdaws (Corvus monedula). Biology letters 10: $20131077-20131077$.

231

232

Davidson GL, Thornton A, Clayton NS. 2017. Evolution of iris colour in relation to cavity

233 nesting and parental care in passerine birds. Biology letters 13: 20160783.

http://dx.doi.org/10.1098/rsbl.2016.0783. 
236 Demongin L. 2016. Identification guide to birds in the hand. Cambridge: Cambridge University 237 Press.

238

239 Feare CJ, Edwards H, Taylor JA, Greenwell P, Larose CS, Mokhoko E, Dine M. 2015. Stars in 240 their eyes: iris colour and pattern in Common Mynas Acridotheres tristis on Denis and North 241 Islands, Seychelles. The Bulletin of the British Ornithologists' Club 135: 61-68.

242

243 Gargallo G. 1992. Ageing in the Dartford Warbler Sylvia undata. Ringing \& Migration 13: 5224456.

246 Hudon J, Muir AD. 1996. Characterization of the reflective materials and organelles in the bright 247 irides of North American Blackbirds (Icterinae). Pigment Cell Research 9: 96-104.

248

249 Karlsson L, Persson K, Walinder G. 1985. Fotografisk documentation av ålders- och 250 könsskillnader hos fåglar - målsättning, arbetssätt och exempel på resultat. Vår Fågelvärld 44: $251 \quad 465-478$.

252

253 Karlsson L, Persson K, Walinder G. 1986. Åldersbestämning av rödhake Erithacus r. rubecula 254 en analys. Anser 25: 15-28.

256 Karlsson L, Persson K, Walinder G. 1988. Åldersbestämning av rörsångare Acrocephalus 257 scirpaceus med hjälp av irisfärg, tarsfärg och tungfläckar. Vår Fågelvärld 47: 141-146. 
259 Karlsson L, Persson K, Walinder G. 1992. Ålders- och könsbestämning av buskskvätta Saxicola 260 rubetra. Vår Fuglefauna Suppl. 1: 31-49.

261

262 Karlsson L, Persson K, Walinder G. 1993. Ageing of Tree Pipits Anthus t. trivialis.

263 Ornis Svecica 3: 69-80.

264

265 Karlsson M. 2016. Kan man åldersbestämma lövsångare på våren? Anser 2: 24-30.

266

267 King JR, Muddeman JL 1995. Ageing and sexing Marsh Tits Parus palustris. Ringing \& 268 Migration 16: 172-177.

269

270 Mérő TO, Žuljević A. 2015. The age of the Great Reed Warbler, Acrocephalus arundinaceus

271 (L.) (Sylviidae), cannot be determined after the complete moult. Acta Zoologica Bulgarica 67

272 (3): 405-408.

273

274 Nogueira DM, Alves MAS. 2008. Iris colour as an indicator of age feature in female Brazilian 275 tanagers (Passeriformes: Emberizidae) confirmed by a molecular sexing technique. Revista de 276 biología tropical, 56 (4): 1629-1633.

277

278 Negro JJ, Blázquez MC, Galván I. 2017. Intraspecific eye color variability in birds and 279 mammals: a recent evolutionary event exclusive to humans and domestic animals. Frontiers in 280 Zoology 14, 53. doi:10.1186/s12983-017-0243-8. 
282 Newton I, Marquiss M. 1982. Eye colour, age and breeding performance in sparrowhawks, 283 Accipiter nisus. Bird Study 29: 195-200.

284

285 Nowakowski JK, Muś K, Stępniewski K, Manikowska-Ślepowrońska B, Szulc J. 2012. Online

286 Database of the Operation Baltic Research Programme. Available at http://akbalt.ug.edu.pl/kssop 287 (accessed March 11, 2020).

288

289 Oliphant LW. 1987. Pteridines and Purines as Major Pigments of the Avian Iris. Pigment Cell 290 Research 1(2): 129-131, DOI: 10.1111/j.1600-0749.1987.tb00401.x.

291

292 Polakowski M, Jankowiak Ł. 2012. Timing of autumn migration and biometric characteristics of 293 migrating populations of European Robin (Erithacus rubecula L., 1758) in north-eastern 294 Poland. Polish Journal of Ecology 60 (4): 797-804.

295

296

Prum RO. 1999. The anatomy and physics of avian structural colours. In: Adams NJ, Slotow RH, 297 ed. Proceedings of the $22^{\text {nd }}$ International Ornithological Congress. Durban, South Africa: Bird 298 Life South Africa: 1-22.

299

300

R Development Core Team. 2014. R: A language and environment for statistical computing. Vienna, Austria: R Foundation for Statistical Computing.

302

303 Rosenfield RN, Bielefeldt J. 1997. Reanalysis of relationships among eye color, age and sex in 304 the Cooper's Hawk. Journal of Raptor Research 31 (4): 313-316. 
305

306 Scholten CJ. 1999. Iris colour of Humboldt Penguins Spheniscus humboldti. Marine Ornithology

307 27: 187-194.

308

309 Smith EL, Cuthill IC, Griffiths R, Greenwood VJ, Goldsmith AR, Evans JE. 2005. Sexing

310 starlings Sturnus vulgaris using iris colour. Ringing \& Migration 22 (4): 193-197.

311

312 Snyder NFR, Snyder HA. 1974. Function of eye coloration in North American accipiters.

313 Condor 76: 219-222.

314

315 Svensson L. 1992. Identification guide to European passerines. Thetford: British Trust for 316 Ornithology.

317

318 Sweijd N, Craig AJ. 1991. Histological basis of age-related changes in iris color in the African

319 Pied Starling (Spreo bicolor). The Auk 108: 53-59.

320

321 Trauger DL. 1974. Eye colour of female Lesser Scaup in relation to age. The Auk 91: 243-254.

322

323 Wilson J, Hartley I. 2007. Changes in eye colour of juvenile Bearded Tits Panurus biarmicus

324 and its use in determining breeding productivity. Ibis 149: 407-411. doi: 10.1111/j.1474-

$325919 x .2006 .00630 . x$

326 
327 Worthy M. 1978. Eye color, size and quick-versus-deliberate behavior of birds. Perceptual and 328 Motor Skills 47 (1): 60-62. 


\section{Figure 1}

Three classes of iris colour used in this study.

$\mathrm{A}=$ class 1 (immature type grey iris) in Robin Erithacus rubecula, $\mathrm{B}=$ class 2 (adult type brown iris) and C = class 3 (iris intermediate between grey and brown) in Goldcrest Regulus regulus. Photos by Jacek Rogoziński.

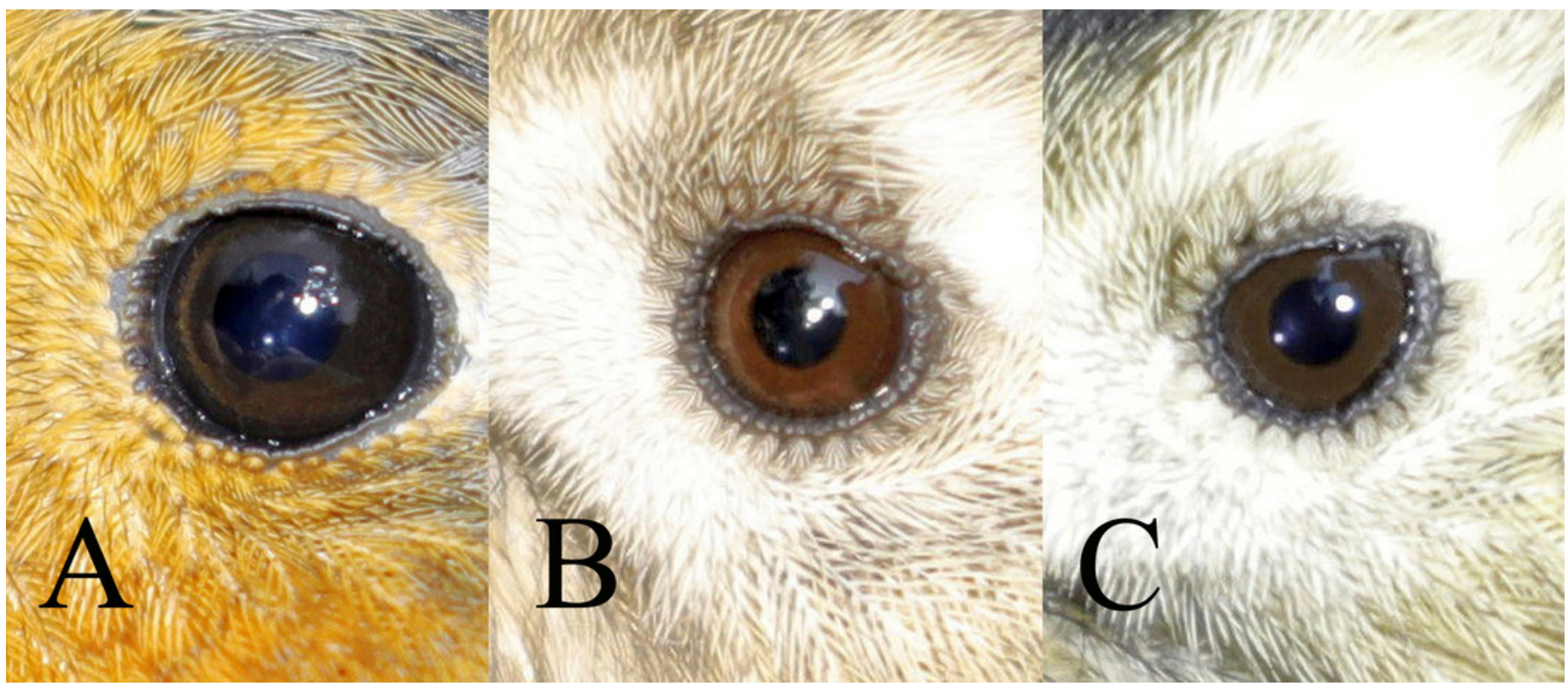


Figure 2

Comparison of the three classes of the avian iris colour used in the study.

$\mathrm{A}=$ class 1 : immature type grey iris, $\mathrm{B}=$ class 2 : adult type brown iris, $\mathrm{C}=$ class 3 : iris intermediate between grey and brown. Drawing by Tomasz Cofta. 


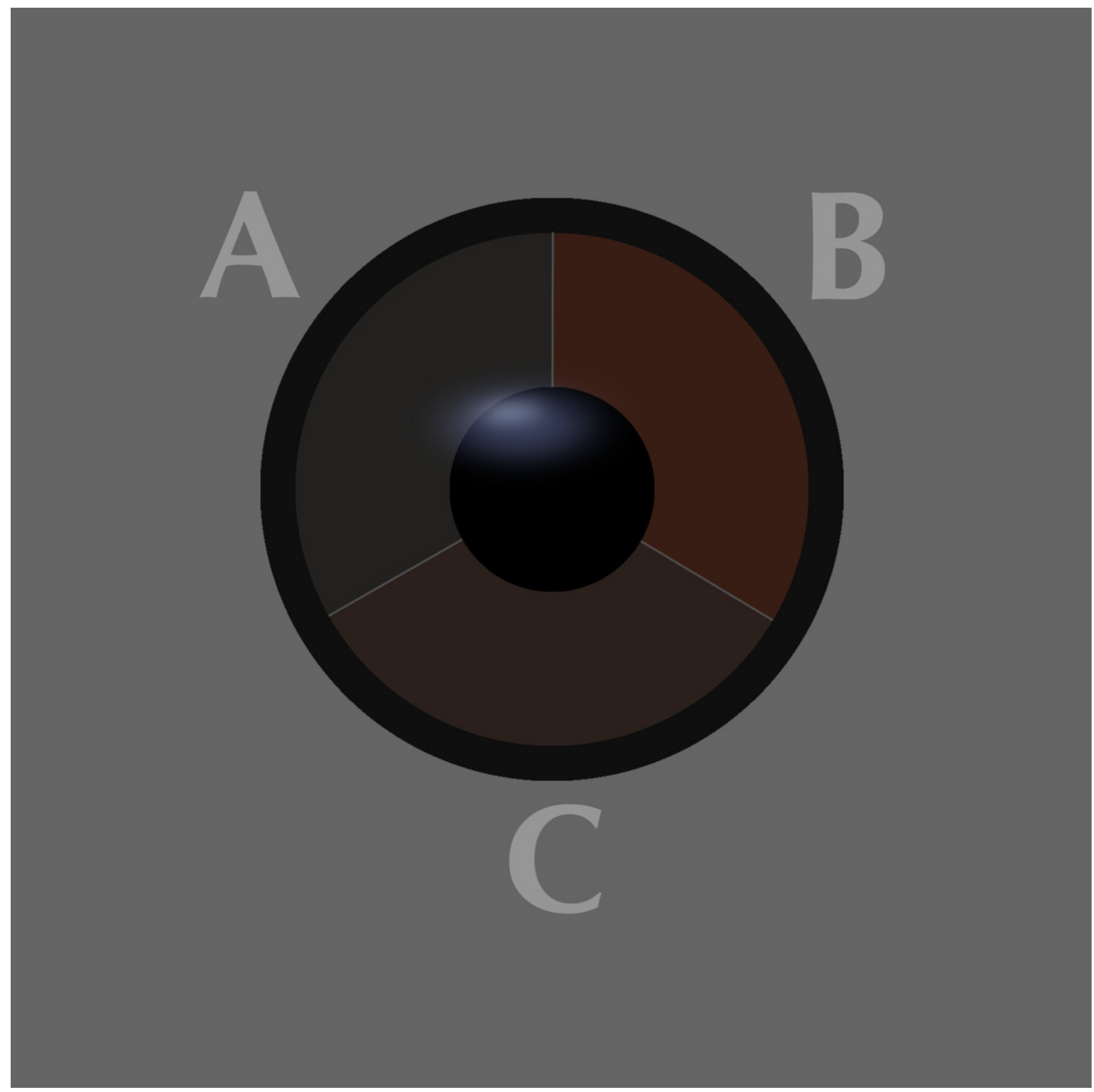




\section{Table $\mathbf{1}$ (on next page)}

Table 1. Numbers of birds from various species and age classes and numbers of individuals with different iris colours. For details see also Methods. 
1

2 Table 1. Numbers of individuals with different classes of iris colour in the studied species; \% 3 percentage of birds aged correctly by the iris colour. Class $1=$ grey iris, class $2=$ brown iris, 4 class $3=$ iris colour intermediate between grey and brown.

\begin{tabular}{|c|c|c|c|c|c|c|c|c|c|c|}
\hline \multirow{3}{*}{ Species } & \multicolumn{10}{|c|}{ Iris colour } \\
\hline & \multicolumn{5}{|c|}{ immatures } & \multicolumn{5}{|c|}{ adults } \\
\hline & \multicolumn{3}{|c|}{ class 1 class 2 class 3} & \multirow{2}{*}{$\begin{array}{c}\text { total } \\
58\end{array}$} & \multirow{2}{*}{$\begin{array}{c}\% \\
93.1\end{array}$} & \multicolumn{3}{|c|}{ class 1 class 2 class 3} & \multirow{2}{*}{$\begin{array}{c}\text { total } \\
24\end{array}$} & \multirow{2}{*}{$\begin{array}{c}\% \\
87.5\end{array}$} \\
\hline $\begin{array}{l}\text { Great Tit } \\
\text { Parus major }\end{array}$ & 54 & 0 & 4 & & & 0 & 21 & 3 & & \\
\hline $\begin{array}{l}\text { Eurasian Blue Tit } \\
\text { Cyanistes caeruleus }\end{array}$ & 25 & 0 & 2 & 27 & 92.6 & 0 & 10 & 1 & 11 & 90.9 \\
\hline Common Chiffchaff & & & & & & & & & & \\
\hline $\begin{array}{l}\text { Phylloscopus } \\
\text { collybita }\end{array}$ & 33 & 0 & 0 & 33 & 100 & 0 & 5 & 0 & 5 & 100 \\
\hline $\begin{array}{l}\text { Long-tailed Tit } \\
\text { Aegithalos caudatus }\end{array}$ & 92 & 0 & 4 & 96 & 95.8 & 0 & 0 & 0 & 0 & - \\
\hline $\begin{array}{l}\text { Goldcrest } \\
\text { Regulus regulus }\end{array}$ & 535 & 0 & 12 & 547 & 97.8 & 0 & 58 & 18 & 76 & 76.3 \\
\hline $\begin{array}{l}\text { Eurasian Treecreeper } \\
\text { Certhia familiaris }\end{array}$ & 21 & 0 & 0 & 21 & 100 & 0 & 2 & 0 & 2 & 100 \\
\hline Winter Wren & & & & & & & & & & \\
\hline $\begin{array}{l}\text { Troglodytes } \\
\text { troglodytes }\end{array}$ & 64 & 0 & 0 & 64 & 100 & 0 & 0 & 2 & 2 & 0 \\
\hline $\begin{array}{l}\text { European Robin } \\
\text { Erithacus rubecula }\end{array}$ & 217 & 0 & 1 & 218 & 99.5 & 1 & 35 & 20 & 56 & 62.5 \\
\hline $\begin{array}{l}\text { Common Blackbird } \\
\text { Turdus merula }\end{array}$ & 116 & 1 & 3 & 120 & 96.7 & 1 & 32 & 6 & 37 & 86.5 \\
\hline Total & 1157 & 1 & 26 & 1184 & 97.8 & 2 & 163 & 50 & 213 & 70.28 \\
\hline
\end{tabular}

